\title{
「IT利用教育の最前線」をテーマにした 関東工学教育協会産学協議会活動報告
}

"Latest Educational Methodology Powered by IT" of the Industry-Academia Conference in Kanto Society for Engineering Education

\author{
京 谷 美代子※ 1,2 \\ 中 山良一 \\ Miyoko KYOYA \\ Ryoichi NAKAYAMA
}

1.はじめに

関東工学教育協会では産業界と教育界が一堂に会して 工学教育に関する活動内容や課題について議論・検討す ることで，相互理解を深め連携して課題解決策を探るこ とを目的に2008年より産学協議会を行っている. 2016年 よりさらに会員サービスを充実するため，3つの重要課 題テーマに分かれて活動することにした．本報告では 「IT利用教育の最前線」をテーマに活動してきたワーキ ンググループ1（WG1）の 2 年間の活動と気づきを報 告する.

IT はICT とも略されることが多いが，本稿ではIT と ICTを同意と捉え，ITを使用する。

\section{WG 1 の活動}

\section{2. $1 W G 1$ の目的}

IT の利用で教育方法は大きく変化している，本WGは 理工学系高等教育や企業内教育においてIT利用を進め ている事例を委員が相互に紹介し合い，その内容をそれ ぞれの組織に持ち帰って今後の取組みに役立てることを 目的としている.

IT 利用は授業中・授業前後に使用する機器・ツール や学習コンテンツの他に, 履修・成績管理システムや図 書館など学内外とのシステム連携など多岐にわたる。本 WG 活動は，その一部にフォーカスするのではなく，委 員の所属する組織の事例を幅広く持ち込むこととした。

\section{2 構成委員と運営}

常任委員は表 1 に示すとおりである。これ以外にテー マにより有識者を講師として招聘, 委員の組織から希望 者がアドホックで参加している. 会合は数力月に 1 度, 委員の教室を提供し合い, 夕方 $2 \sim 3$ 時間の討議と懇親 会で活発な意見交換を実施している.

\section{3 活動内容}

2 年間で 8 回会合し, 計 18 テマを交換し合った. また 直近の 2 回では課題や今後の活動の方向性を議論した.

2018 年 3 月 19 日受付

※ 1 関東工学教育協会産学協議会

※2(株) FUJITSU ユニバーシティ

*3工学院大学
表 1 WG 1 委員

\begin{tabular}{|lr|l|}
\hline \multicolumn{2}{|l|}{ 京谷美代子 } & WG Iダ, (株)FUJITSUユニバーシティ \\
\hline 中山 & 良一 & 産学協議会会長, 工学院大学 \\
\hline 山口 & 佳和 & 産学協議会副会長, 千葉工業大学社会システ \\
厶科学部経営情報科学科
\end{tabular}

以下にその概要を述べる.

(1) 共有テーマ

(1)「MOOCの活用」高橋委員

日本におけるMOOC (Massive Open Online Courses）であるJMOOCと, その企業内教育での活動紹介, 社内研修所に扔いて JMOOC ・ 理工系基礎科目シリ ーズを活用した事例の紹介があった。本シリーズは, JMOOCから国立高専機構や長岡技科大への依頼によ るものであり，2016年度後半から続々と公開予定で, 今後も社内での活用を推進する旨報告があった。

(2)「富士通のIT活用による学びの変化」岡田委員

人材育成へのIT活用の流れ, 富士通グループの研 修でのIT 活用例， eラーニングコンテンツ設計での工 夫について紹介された，全社員が参加・受講する必修 eラーニングとして, 受講者の学習意欲を高め, 能動的 な学びにつなげていくための工夫として, 紙芝居形式 ではなく参加型（インタラクティブ）のコンテンツ作 
成が紹介された.また将来に向けては, 各種デー夕を統 合活用したパーソナル学習環境を構築していくこと の重要性などが示された.

(3)「実験形式による組达みシステム初級教育の実践」 日本大学 五味様

学部三学年を対象にした組込みシステム初級教育と して，専門科目と連携した課題実験を実践した．今回 適用した実験スキームとゴールッリーを用いた実験 内容の設計は, 座学や実習だけでは難しい (1) 組达み システムへの関心, (2) 組达みシステムの技術理解, (3) 技術者としてのコンピテンシーの向上に効果があっ た旨報告された。

(4)「NECの取り組み〜スキルDBなど」但田委員 エンジニアを中心とした人事制度とそれを支える人 材育成情報管理システム，そのベースとなるプラクテ イスファイルの考え方が紹介された。

情報管理システムには社員/組織情報, 教育受講情 報, 資格, TOEIC, 情報発信活動などの情報が保存 されているが，2016年度より運営スタートした新シス テムでは学会活動などオープンな活動情報やプロジェ クトとしての活動情報も保存するよう仕組みを強化し た.

(5)「カンタンeラーニングコンテンツの作り方! 内製化 手法」(株)WARK 長瀬様, 横江様

音声や映像を取り込んだ $\mathrm{e}$ ラーニングコンテンッの 作り方が紹介された. PowerPoint2016は機能追加され 音声や動画を組み込みやすくなった。またツールを使 うことでPPTからeラーニングの標準である SCORM 形式のコンテンツに変換することができる，スマホ用 コンテンツ作成や素材集も紹介された。同社では eラ ーニングコンテンッ作成の研究開発を実施している が, 教育機関での内製に向けた教育も定期的に開催, または個別対応しているとのことであった.

(6)「教育ビッグデータの解析から見えること」(株富士 通ラーニングメディア 戸田様

同社がこれまで社内外の教育を通して貯めてきたe ラーニングのビッグデータ解析事例が紹介された。最 終テストの結果が良い人は, 学習期間の最初から計画 的に学習を開始する傾向. 通勤時間帯の継続学習時間 は10分程度なので, コンテンッは10分単位で作ってお くのが良い. 企業の一般学習者は朝·夜の通勤時間帯, マネージャは昼休みの学習が多い，学生は夜型学習が 多く, 学習時間の多さは採用時期とも連動している.

(7)「教室でのIT利用」(株)内田洋行 蓜島様

Future Class Roomで体感できる場を提供してい る. プレゼンテーションッール wivia 4 は複数のPCや タブレット端末とプロジェクタを無線でつなぎ（煩わ しい配線の手間を省略)，コミュニケーションを支援 する. AV 制御システム codemariは様々な AV 機器を タブレット端末で簡単に操作できる。これは大阪工業 大学が梅田に開設した「都市型新キャンパス」等でも 採用された，教員・学生の反応を同時に記録・再生 ができる双方向型学修コミュニケーションッールPF-
NOTEや学生同士のコミュニケーション活性化を支援 するMOVARIなども紹介された。

(8)「CRDSシンポジウム“IoT/AI時代に向けたテクノ ロジー革新ー大変革時代の新機軸とはー"に参加し て」小口委員

2017年 3 月 7 日に開催されたシンポジウムでの議論 が紹介された，進化するIT技術について, 大学での教 育は何をしておくべきかを考える必要がある，企業で は新しい言語や AIを活用できる実践教育が必要にな っている. 本WGとして方針を出してはどうかと提案 があった.

(9)「教育にゲームの力を取り入れる〜ゲーミフィケー ション導入の考え方」東京大学 藤本様

ゲーミフィケーションは, 広義では「社会のために ゲームの力を活用する取り組み全般」, 㹨義では「ゲ 一ム要素, ゲームデザインの手法」をゲーム以外のシ ステムやサービスに活用する」とある。活用事例とし て米国ホワイトハウスでのシリアスゲームジャムや福 岡市と九州大学がリハビリ分野のシリアスゲーム商品 化, 防衛省のサイバーセキュリテイ分野でのシリアス ゲーム開発が紹介された。

ゲームの要素にはゴール, ルール, フィードバック システム, 自発的参加があり, 教育に近い要素であり, ゲーミフィケーションが起こす変化「知識習得」「行動 変容」「態度変容」は教育と共通する. ゲームなので失 敗しても良い空間ということで参加意欲がこれらの変 化を促進する。もちろんゲームの教育利用の長所・短 所があり, 学習者ごとに効くゲーム要素は異なるので, 考慮して進めることが肝要とのことであった. STEM 教育（プログラミング含む）をゲーム化する試みが米 国で始まっていると紹介された。

(10)「海外オープンエデュケーションの国内利用に向け

て」中村委員

NPO法人Asuka Academyでは世界最高の学びを日 本語で, 無料で学ぶことを目的にMITなど海外トップ 大学の OER (Open Educational Resource) コンテンツ を無償公開している。翻訳はボランティアで, 企業人 や大学生・高校生が翻訳作業に参加している。「MIT $+\mathrm{K} 12$ Videos」を広尾学園の高校生が翻訳しており, 英語学習に加え, 専門教育への興味促進に役立ってい る. 現状は技術系コンテンツが多いが，文化的なもの も増えており, 経済もこれから増やしていく。

(11)「速報 教育ITソリューション」京谷委員ほか

2017年 5 月17日〜19日に開催された「教育ITソリ ユーション2017」について意見交換を行った。 基調講 演「東京工業大学の教育改革〜学びの刷新」, セミナー 「iTeachers TV LIVE教育ICT の先駆者が語るICT 活 用の秘訣とは」, 特別講演「子供達が将来世界で活躍 するために! 小学校からプログラミング教育を」につ いて京谷委員から紹介した. 今後小学校からITに馴染 んだ学生が育っていくが, 大学教育はIT利用できてい るか, 大学教員のITリテラシーは十分かとの問いかけ があり，これは企業も同様との意見があった. 
(12)「『みらいDOORS』のご紹介とITを使用した教育関 連の事例紹介」(株富士通ソーシアルサイエンスラボ ラトリ 片瀬様, 川瀬様

共創を支援する教室環境やッールが紹介され意見交 換を行った. 事例としてカード情報の活用やコメント 投稿の活用，コンテンツの表示や分類機能などのデモ があり，コメント投稿の活用ツールを参加者全員で体 験した. 各自のスマートフォンにアプリケーションを インストールすることなくQRコードを読み込むだけ でコメント投稿ができ，それをタッチパネルディスプ レイで全体表示し，コメントの分類や追加コメントの 発信等を行った.

(13)「マイクロラーニング活用事例」(株)ビジネスコンサ ルタント 廣瀬様

ATD (Association for Talent Development) の年 次大会でも昨今ホットな話題となっているマイクロラ ーニングの必要性やコンテンツの設計・開発の仕方が 紹介された. 大人の学びとしてパーソナライズ化も込 みで企業参加者の関心が高かったが, 大学でもマイク ロラーニング的なコンテンツ開発を試行しているとの 意見があった，学習時間の自己管理についても議論が あり，米国に比べ自己管理力が弱まっているとの指摘 もあった。

(14)「バーチャルクラスルームとその周辺」マインドエ コー代表 香取様

急速に広まるバーチャルクラスルームの状況と実施 上の留意点などが紹介された．グローバル化の進展に より, 学習の機会・出会いの機会・討論の機会がワー ルドワイドに広がっている。講師にはトレーナーから ファシリテータのスキルが必要である。 バーチャル環 境でワールドカフェ（グループ討論の一手法）も可能 だが, 参加人数が増えるとメインホストに加えてコホ ストやテクニカルサポートチームも必要とのことであ った.

(2) 課題と身近なテーマ

1 年半の間に「IT利用教育の最前線」のテーマを共有 してきた。また私立大学情報教育協会が 2012 年に提言し た資料 ${ }^{1)}$ や文部科学省 ${ }^{2)}, 3$ 他様々な機関が調查結果 ${ }^{3)-5)}$ ベストプラクティス ${ }^{6)}$ を紹介していることも共有した.

しかし, 教育現場でのIT活用は思うように進んでいな い. 大学での推進の難しさとして, 組織的に進めるとし てもITに詳しい人がいない. IT 専門の先生はいるが個 人で動いており, 組織全体を推進する権限・モチベーシ ヨンがない，企業ではトップダウンで一旦活用が決まれ ば推進されるが，大学では推進組織で準備しても説明書 を見ただけでは使えず，個々の教員が工夫して実施して いる. また効果がわからないと使わない教員もいる．従 って, 大学においては, ITツールを使う事を誰が承認・ キックオフ・普及するか, そのためのスタッフをどうや って確保するか, どのように教員のリテラシーを確保し モチベーションを向上させるのかを, トップダウンで粘 り強く解決していくしかない. IT 設備導入, 運営の人材 獲得も含めた予算確保が一番の鍵であるとの課題を共有
した.

一方，比較的取り組みやすく実績があるものとして, 以下の身近な活用テーマを共有した。 ただしこれらにお いても，すべての教員が活用するにはITッールのさらな る進化や教員のITリテラシー強化が必要である.

(15)テスト作成

ITによるテストの作成は学生・教員双方にメリット がある. 回答用紙をPDF化したものにペンでコメント し返却しているが，出先でも採点できるので便利との 意見があった。一方ツールはまだ使い辛いとの意見が 多かった。

JABEEではテスト用紙の 5 年間保存が義務付けら れているので, 電子化のメリットがあるとの意見があ った。

(16)電子テキスト

ある企業ではテキストの電子化がほぼできたとの紹 介があった。ソフトを含むクラウド環境構築をアウト ソースして開発・構築した。iPadはレンタルしている。 社内に技術者はいるが，アウトソースすることでスピ ーディに環境を構築できた。 カラー表示, 拡大機能, 検索機能などで見やすい，紙のテキストは保管に困る が電子デー夕なのでPCで簡単に保管できると好評と のこと. 紙をパラパラとめくるスピードは出ないが, メリットの方が大きい.

大学でも電子テキスト化は進められており, テキス トのサーバへのアップ, 学生のダウンロードッールも 簡単な操作でできる，誰がダウンロードしたかも把握 できて良い．大学の講義は枚数が非常に多いのが特徴 である．教員相互で利活用できれば良いとの意見もあ った. 学生のダウンロードを増やす仕掛けも必要で, そ のためには毎年新しい情報を発信しないと学生は興味 を持たない. 学生の目線に立って, 彼らが日々使うッー ルをベースにすると使用されやすい (Line と Dropbox でかなりのことはできる）といった意見があった. (17)反転学習

動画の撮影は簡単になっている. 科目によって求め られる精度が違うので, スマートフォンでの撮影でも 良いものもある。また, MOOC/JMOOCやYouTube 動画を授業で活用する例も紹介された。

一方で，パブリックッールの活用に扔けるセキュリ ティの問題や, コンテンツの流用に扔ける著作権の問 題もIT活用において, さらに注意が必要との意見があ った.

(18) $\mathrm{AI}$ など今後の活用テーマ

$\mathrm{AI}$ の活用も進み始めている. ある企業ではプログラ ムの良し悪しを AIが判定するッールを開発しており， プログラミングカ向上にゲーミフィケーションの要素 も取り入れることを検討すると紹介があった。

AIをPBLの評価で使えないかとの意見もあった. 現 状では教員やTAがチェックしている「熱心さ」の部 分を, 画像や音声, センサーでルーブリックの自動判 定としてできないか，それに近い取り組みを研究して いる事例もあると報告があった。 
学生やエンジニアの目指すキャリアの種類を登録し ておくと, 受講すべき講座のリコメンデーションをし てくれる機能についても議論した．個人情報へのアク セスや履修科目, 教員アドバイスなど育成情報の蓄積 も必要である。コールセンターでは過去の対応実績が すべて記録されており，どのオペレータが電話を取っ ても過去の経緯を見つつ対応できる。このようなシス テムが教育現場でも必要との意見があった。

（3）今後の活動の方向

2 年間活動して様々なテーマを共有してきたが, どこ まで実践に持ち込めたかについては定量的に把握できて おらず，2018年から始まるWG 第 2 期はさらに実践に向 けて活動すべきという意見がある.

一方で視点を変えた活動案もある. IT ×教育はさまざ まな形で論じられている。「教育におけるIT活用 (WG 1 の第 1 期テーマ)」,「ITを専門分野とする学生へのIT 専 門教育 (WG 4)」,「学生全員が持つべきITリテラシー」 などだ. ITはすべての分野のベースとなってきている が,「工学ならでは」という観点で,「工学部の学生に必 要なIT教育」や「工学部の教育ならではのIT活用」と いった切り口もある.

会員同士の活動を盛り上げる場として, どのようなテ ーマで進めて行くのが良いか, 議論しつつ決めていきた い. 活動に興味のある新委員・オブザーバも歓迎したい.

\section{3. おわりに}

年次大会・研究講演会では大学や企業の枠を越えて, さまざまな議論を重ね, 多くを学ぶことができ有意義な 活動であった，日本はオープン教育リソース (OER) や バーチャルクラスルームの活用が遅れていると言われて いるが, 働き方改革の議論が続いている中で, 社会人の 学び直し教育や企業におけるテレワーク・パートタイム 社員向け研修などへのIT活用も期待される.グローバル な教育体制にむけてもIT活用は重要だ. 今後も議論を続 けて行きたい.

\section{謝辞}

最後にご多忙の中, 高い出席率となりましたWGに, 会場提供, 講師紹介, 活発な議論等積極的にご協力頂い た委員のみなさま, 惜しみなく知見をご披露頂きました 講演者のみなさまに感謝申し上げます。また, 会合の準 備や, 懇親会含め予算を上手く工面し委員の交流をご支 援頂きました佐々木徹関東工学教育協会事務局長 (当時) に心よりお礼申し上げます。

\section{参 考 文 献}

1 ）私立大学情報教育協会事務局 :「大学教育への提言」 一未知の時代を切り拓く教育とICT活用, Webペー ジ, http://www.juce.jp/LINK/teigen.html, 2012, 参 照日：2018-3-16

2 ）京都大学：平成25年度文部科学省先導的大学改革推 進委託事業「高等教育機関等におけるICTの利活用 に関する調査研究」, Webページ, http://www.mext. go.jp/component/a_menu/education/detail/__ icsFiles/afieldfile/2014/05/19/1347641_01.pdf, 参照 日 : 2018-3-16

3 ）大学ICT推進協議会：2015年度調査「高等教育機関 等におけるICTの利活用に関する調查研究」, Webぺ ージ, https://axies.jp/ja/ict/2015, 参照日 : 2018-316

4）大学ICT推進協議会：BYODを活用した教育改善に 関する調査研究, Webページ, https://axies.jp/ja/ ict/axies2017_byod_slides, 参照日 : 2018-3-16

5 ）富士通総研 : 教育分野における先進的なICT利活用 方策に関する調查研究, 平成27年 3 月, Webページ, http://www.soumu.go.jp/main_content/000360824. pdf, 参照日：2018-3-16

6 ）私立大学情報教育協会事務局：私情協のICT利用に よる教育改善研究発表会, Webページ, http://www. juce.jp/LINK/houhou/houtop.htm, 参照日 :2018-316 